\title{
Sociology of Culture and Cultural Studies: Towards a Postsocialist Reconciliation
}

\author{
Ksenija VIDMAR HORVAT \\ Department of Sociology, Faculty of Arts, University of Ljubljana, Slovenia \\ ksenija.vidmar@ff.uni-lj.si
}

\begin{abstract}
This paper investigates the relationship between the sociology of culture and cultural studies. It is argued that the relationship calls for a more in-depth inquiry because the two strands of analysis of culture bear much in common; yet, due to mutual misconceptions and misunderstanding of the research goals, their common agenda is often ignored (or even opposed). In addition, the shared legacies are often obscured by geographic and intellectual cultures that fall within the dividing lines between Western (democratic capitalist) and Eastern European (postsocialist) epistemological orientations in studying social change. As a result, both fields are losing in their theoretical power and practical pedagogy. The paper points to the origins of some of the mutual misconceptions with the goal of showing the potential for the mutually enforcing intellectual energy if the sociology of culture and cultural studies shift their relationship from practicing ignorance to embracing a dialogue.
\end{abstract}

Key words: sociology of culture, cultural studies, postsocialism, Marxism, class, critical pedagogy, intellectuals

\section{Introduction}

This paper investigates the relationship between cultural studies and the sociology of culture. The main objective of this investigation is to pave the way for a better understanding between the two fields; and to map sites of common critical concerns that can, in my view, enrich both approaches as well as to equip them to deal better with the research agendas derived from processes of globalization and, in the area specific context, of Europeanisation.

The objective stems from observation of a considerable gap in understanding between the two fields, which is especially pronounced in, but 
by no means reserved for, ${ }^{1}$ the postsocialist academic environments with a stronger (and longer) tradition of the sociology of culture. In its global fame, cultural studies have gathered the aura of both a revolutionary turn in studying society through culture; and a theoretical regression to the "cultural turn" (Jameson, 1991) where all social relations are now being explained by culture. The latter critique is most pronounced in circles close to the Marxist tradition of the sociology of culture. Furthermore, in the postsocialist intellectual sphere (Habjan, 2010; Močnik, 2009), the critique is extended onto the method. The main "sin" of cultural studies seems to be the very politics of its academic practice: in studies, as opposed to theory. Empirical research - which for cultural studies presents a major contribution to critical theory of culture - into the Marxist sociology of culture signifies a turn away from theory. Cultural studies is seen as a pre-theoretical academic practice, a bricollage of case studies with no significant contribution to the advancement of Theory.

As this attitude may be described in a slightly exaggerated way and may in fact pertain only to certain circles, entrenched with geographically and politically specific intellectual wars of postsocialist Slovene academia, to which the author belongs, to be able to focus in this paper on the critical loss for both groups/schools as a consequence, I intentionally ignore the culturally specific contexts of the struggle. ${ }^{2}$ Indeed, as I will suggest in this paper, the conflict that is clearly foremost as an occasion to develop case study research, may also be seen as reflecting a broader sociological issue of conceptualizing social change through structure and/or agency; and the divide in the Marxist paradigm between determinists and culturalists (Lucács, Goldmann, the Frankfurt School). Therefore, rather than dwelling on the conflict as such, the purpose of my analysis is to illuminate key conceptual miscomprehensions that frame the conflict in a more profound

\footnotetext{
${ }^{1}$ The analysis is in part based on auto-ethnography of my own academic experience and formation in both fields; this formation took place at the University of California where I entered the PhD program of sociology of culture but became a cultural studies person; and at the Department of Sociology at the Faculty of Arts, University of Ljubljana, where I took a teaching position in the sociology of culture as a cultural studies person: in both academic environments, some of the key issues of misunderstanding between the sociology of culture and cultural studies emerged.

${ }^{2}$ In a way, the debate is also impossible; in their work, major critics of cultural studies in Slovenia (Habjan, 2010; Močnik, 2009, see especially p. 432) provide no concrete references of their critique.
} 
and transcultural way: and impoverish theory on both sides - and indeed undermine the social power of Theory.

This goal is pursued in three steps. In the first part of the paper, a brief review of the main theoretical contribution of cultural studies is outlined; this is followed by a similar review of the sociology of culture in the second part. With the term cultural studies, I refer to the specific tradition of the Birmingham School. ${ }^{3}$ In my review of its contribution, and the prolongation of this British legacy into the U.S. academia, I rely on the historical review of the most influential works in the three subject specific areas: feminist media studies, race and postcoloniality. Sociology of culture refers to the specific intellectual field with roots in Marxism and post-Marxism. ${ }^{4}$ Sociology of culture is, of course, a broader field than this. The narrowing of the focus is justified in two ways: the main critique of cultural studies in Europe comes mainly from Marxist circles. This is true for British, French and, for the matter of this paper, Slovene (and, arguably, other exYugoslav) circles. This is indeed an interesting paradox, given that the critique is usually most fierce when fully addressed to the post-Marxist strand of cultural studies, which presents a lesser problem for other traditions of the sociology of culture, such as Weberian or symbolic interactionist. Secondly, and related to the first, in socialist and postsocialist academic cultures, other traditions of the sociology of culture have been less influential. For instance, North American symbolic interactionism (Howard Becker) or production of the culture paradigm, to mention only two, have had only a minor role in teaching cultural theory. ${ }^{5}$

\footnotetext{
${ }^{3}$ Although cultural studies originate in the concrete institution and programmes of the Birmingham Centre for Contemporary Cultural Studies, as a source of theoretical orientation and research inspiration CCCS has moved to the backstage of intellectual attention of younger scholars; more often, it becomes synonymous with the field of cultural studies tout court without acknowledging the specific political context within which the Centre launched its programme. Although there are many ways of doing cultural studies, and manifold strands which indeed prevent granting the field the status of a unified discipline, when referring to cultural studies in this paper, we have this particular tradition, and its derivations, in mind.
}

${ }^{4}$ Again, there are many sociologies of culture which may mean different things in both theory and practice. Here, we refer to Marxist-oriented analysis of social formation(s) and the power structures of relations of exploitation.

${ }_{5}^{5}$ To illustrate the point, there is only one copy of Becker's Art Worlds available in all public libraries in Slovenia; it is located in the library of the Sociology Dept. at the Faculty of Arts and was ordered by the author of this paper. There are three copies of Wendy Griswold's Cultures and Societies in a Changing World; and not one copy of Richard 
Finally, the third section of this paper investigates shared intellectual agendas and missing critical encounters; this is done through comparison of research agendas and epistemologies of both fields. In conclusion, the findings are illuminated in the context of critical pedagogy and the commitment of critical intellectuals on both sides of the field of theoretical struggle to reclaim the vanguard role in mapping social change.

\section{Cultural studies: a new player on the field}

In a necessarily simplified way, cultural studies can be defined as the field of research that focuses particularly on popular culture; takes this culture seriously which, inter alia, means that it does not differentiate between high and low cultural production; and does the research with the principal goal of studying popular resistance and emancipation (Cruz, 2012; Fiske, 1989; Grossberg, Nelson and Treichler, 1992; Hall, 1993; Vidmar Horvat, 1998). The loose yet distinct epistemological orientation has brought cultural studies a certain hegemonic power and intellectual prestige: at the same time, precisely because of its elusiveness, cultural studies is also in constant struggle with critics who downplay its academic value. What tends to be underlined as intellectual freedom in cultural studies is undermined by the academic traditionalists as inconsistent, incoherent and - as an unacademic endeavour.

The reputation of the un-academic, non-discipline like status of cultural studies may be described as "part of the package" by which the struggle to resist definition, control and classification - the standard procedures that operate within academic state apparatus and by which intellectual prestige is being regulated and (re)produced - is used as a tool of legitimation. Therefore, it may be all the more intriguing that the same critique - of the lack of Method, Theory and Organization - which is usually associated with intellectual conservatism, is shared also by the Left. The situation calls for a closer look. Before suggesting sites of potential short circuit, in this chapter, I first provide a brief insight into the field and its praxis.

Instead of a distinct method, cultural studies offers a list of studies. Studies are conceptualized as both cases as well as unique projects: every

Peterson's The Production of Culture. Although the availability of the books in libraries does not tell much about the actual circulation of scholarly literature (private libraries, internet books, etc), the limited availabilty in university libraries shows that they are not used as obligatory course study literature. 
analytical intervention aspires to become a model for doing analysis while at the same time claiming methodological originality that does not transpire repetition and copying (Vidmar Horvat, 1998). Moreover, relying on manifold research strategies and conceptual diversity may produce analytical platforms that are in conflict: psychoanalysis, semiotics, structuralism and Marxism on the one hand, ethnographies and microsociologies of the everyday on the other. The tensions reflect the cultural studies key paradigm itself, namely the focus on the production of meaning that is understood as an always complex, contingent and ambiguous process.

Despite elusiveness, there are three distinct features that unite diverse practices of doing cultural analysis under the umbrella of one field. These are explained below.

The marginalized intellectual. This relates to the social location and cultural background of the cultural studies pioneers. Raymond Williams and Stuart Hall, the key authorities of British cultural studies, are both figures from social, cultural and geographic peripheries. The marginal social pedigree plays a formative role in the intellectual biographies of both authors; and features as a shared intellectual legacy of cultural studies. Hall describes the experience in his memorial account of the influence of Raymond Williams on his own personal development: "There was another 'elective affinity' which made me feel close to him, despite our enormous differences in temperament, character, background, ages, generation and formation: our response as 'scholarship boys' from the peripheries of English culture to our first encounter with the institutions which were at its very centre as a dominant cultural system: Oxbridge" (Hall, 1993: 349-350). Williams arrived at Cambridge with the luggage of Wales culture, in the circles of the British national cultural elitism of Englishness seen indeed as the "other culture"; Hall entered the intellectual centres from the peripheries of (black) race. Consequently, because of his experience of cultural exclusion, Williams in his writing revived the holistic humanist version of culture as a "whole way of life"; marked by his racial exclusion, Hall asked "whose way of life" and instead of holism contributed the theory of representation that emphasized the fragmentation, fluidity and nomadism of the subject (Hall, 1993).

In the US, the marginality of the intellectual had a different political context. The location was that of the subaltern. In the UK, cultural studies 
grew to evolve around popular culture and the related research agenda on class, gender, entertainment and media; the contribution of the US cultural studies was explicated more in relation to race and postcoloniality. This coincided with the political situation that triggered demands in the 1970s and 1980s for the inclusion of the marginalized and their access to education. Chicano studies, black studies, and women's studies programs begun to emerge. This was most pronounced within the university system in California where "colleges and universities began to move toward engaging and including marginalized subjects (subject-matter as conceptual content as well as demographic subject-groups)" (Cruz, 2012: 277). Cultural studies entered the academia when these programmes were already running and thus, the conjuncture created out of this encounter moved cultural studies more towards the politics of identity, "strategic essentialism", and postcolonial subjectivity (Cruz, 2012: 279).

Strategic essentialism "has enabled achievement: subjects became present in the American academy who simply were not there before, who wrenched out of exclusionary institutions new places and positions on behalf of seeking certain desired outcomes" (Cruz, 2012: 280). This development brought about a new situation, best described by the title of Spivak's book Outside in the Teaching Machine (1993); a situation of inclusion of the marginalized and their accession to the privileged positions of the educated elite.

The decline of the power of the Text. Secondly, cultural studies undermines the structuralist stability of the text. This again relates to the question of authority and distribution of knowledge in academia, but tackles it from the outside: in the sphere of the reception. In structuralist reading, "The function of a text is to position the spectator to receive certain favored - and restricted - meanings which the text 'manages' for the viewing subject in keeping with dominant ideology" (Pribram, 1988: 4). This position was questioned by the scholars at the Centre for Contemporary Cultural Studies in Birmingham who argued from the very beginning for the studying of texts as consumed within concrete social and cultural settings (for the discussion of the debate, see: Fiske, 1989; Moores, 1993). To see the reader only as a function of text, David Morley has argued in response to screen writers (as the most influential bloc of structuralism on the island), "serves to isolate the encounter of text and reader from all social and historical structures and from other texts. To 
conceptualize the moment of reading/viewing in this way is to ignore the constant intervention of other texts and discourses, which also position "the subject"' (Morley, 1992: 140).

A major force of deconstruction, however, came from feminist media studies. Consistent with cultural studies' interest in low brow, the research of soap opera has offered a most vital ground on which to observe contestations of textual codes unfolding in the process of their consumption (Ang, 1985; Brown, 1990; Modleski, 1988; Seiter et al., 1989). The emphasis of the genre on emotions, empathy and talk - which, in patriarchal culture, are all signifiers of a female domain - implies the female viewer who, through identification with the television characters, is affirmed in her social location at home and in the family. Moreover, with its daily incorporation into the ordinary life and routines of the housewife, the textual codes are re-enforced by the practice of watching. In the combined effect, the genre can be rightfully dismissed as a conservative ideological form that operates to secure the boundaries of woman's domestic containment and reproduce her patriarchal enclosure within the confines of marriage and motherhood. For feminist media ethnographers, however, it is not sufficient to study the ideological properties of soap opera texts and their effects on female audiences, for, in their view, the meaning of soap opera programmes is produced within the specific context of women watching their favourite show. Watching the genre designates a sphere of female pleasure where viewers may appropriate textual meanings to serve their specific needs and interpretive practices, which may both comply with and defy the intended function of the text. Women's gossip networks, in particular, have been discussed in terms of acts of defiance against dominant culture. The hegemonic (male) culture, which ascribes to soaps and gossip derogatory aesthetic and social connotations, meets in "the pleasure of women's talk" a form of resistance (Vidmar Horvat, 1999).

Challenging the authority of interpretation. Cultural studies relegates the authority from the text to the reader. This means a laborious empirical work of studying different audiences and multiple locations of concrete readers; more to the point, it also means a deconstruction of the authority of the Interpreter: his reading is now downgraded to become only one of many. Again, institutional contexts are pivotal to this degradation. The method of ethnographic work, employed by cultural studies, came from the 
influential work of James Clifford, the founder and director of the History of Consciousness program at the University of California in Santa Cruz (Vidmar Horvat, 1995). In his milestone work The Predicament of Culture, Clifford questions the authority of representation. In particular, he raises the issue of the power to speak especially on behalf of marginalised people and cultures. Ethnographic scholarship, Clifford argues, has tended to ignore the histories of the disempowered and "their ability to invent future" (Clifford, 1988: 9). Clifford's ethnographic paradigm aims at recovering the voices of the excluded and abolishing traditional imperial intellectual treatment of the "other".

The institution and intellectual closeness between the History of Consciousness and cultural studies allows for his method to become adopted as a critical methodological tool in cultural studies; with his radical critique of classical modern anthropology, Clifford's ethnography also serves as an important corrective to the Westernocentric tradition in research. In the context of the rise of the US in adopting a multiculturalist model of society in the 1980s and 1990s, cultural studies contributes to amplifying the institutional and disciplinary voice of the subaltern; and makes an important move towards decolonization and de-racialization of (modern) reason.

\section{Sociology of culture: a Gramscian challenge}

The global rise of cultural studies begun in a specific historical moment of the 1970s and the 1980s, marked in the U.S. by the Civil Rights Movement and the Feminist Movement, and in (Western) Europe by anti-elitism and the demise of the public educational sphere. Cultural studies was a British export, and it landed on soil that proved more fertile across the Ocean than across the Channel; in continental Europe, the progression of the paradigm was slow and, even today, cultural studies can be seen more as an accompanying source than an autonomous field of research; it is tolerated by the established disciplines, occasionally employed (most often as a method derived from the theory of representation), but kept at the margins of "serious" academic work. The marginalization of the field can be explained in two ways. The first relates to the above-mentioned historic circumstances of its global, primarily West-wide expansion; the second relates to the missing programmatic alliances with continental critical theory. 
To begin with the latter, the usual critique of cultural studies is directed towards its alleged abandonment of class. The charge is symptomatic as it is the exact opposite of the conservative stand that cultural studies "was too Marxist from the start" (Cruz, 2012: 260). Not Marxist enough or too Marxist, as Cruz provides an insightful comment, "both are scenarios that have grown over the last four decades to indict cultural studies for not being amenable to discipline. Cultural studies was successful in presenting a much-needed alternative to disciplinary rigidity [...] Yet it drew attacks for its failure to promote a sense of discipline and its anti-disciplinary posture. From the outset, cultural studies harboured the irony by having to work with this Janus-faced profile" (Cruz, 2012: 260-261).

Class is a social category that cultural studies research recognizes and even employs as a variable, but does not grant it the status of a constant in the "last instance". In cultural studies, when considering the production of meaning and the system of representation, class is always crossed with other relations, such as gender, sexuality, race, and ethnicity; it is deemed fairly elusive in terms of producing ideological affiliations (middle class is not an absolute negative in the terrain of social conflict); and is not treated as either in need of intellectual guidance nor as revolutionary sui generis.

Yet, criticism of cultural studies is borne along on a significant portion of "unfortunate historical, if not outright political amnesia" (Cruz, 2012: 258). Cruz explicates the view: "What ensues is an analytical dualism: the historical importance of cultural studies itself is trivialized by this abandonment, while amnesia simultaneously operates to trivialize subjectivity and identity issues that complicate class. As cultural studies is trivialized on the basis of such analytical errors, the arguments that seek to salvage class perspectives revert to the position that cultural studies could be redeemed if it returned to carrying out the older but rigorous approach to political economy and class - as if the theoretical irruption that we have come to know as western Marxism or cultural Marxism, which are so important to the broader intellectual circles that enabled cultural studies to emerge, has never existed" (Cruz, 2012: 258).

In the original context of the CCCS, cultural studies "struggled to comprehend, take stock, address and critique the debates on how to grasp the problem of culture" (Cruz, 2012: 262). The work of Raymond Williams, E. P. Thompson and Richard Hoggart that incorporated the legacies 
of the Old and the New Left was highly influential, and Marxist heritage was among them. ${ }^{6}$ Stuart Hall writes, "I came into Marxism backwards: against the Soviet tanks in Budapest, as it were. What I mean by that is certainly not that I wasn't profoundly, and that cultural studies then wasn't from the beginning, profoundly influenced by the questions that Marxism as a theoretical project put on the agenda: the power, the global reach and history-making capacities of capital; the question of class; the complex relationships between power, which is an easier term to establish in the discourses of culture than exploitation, and exploitation [...] These important, central questions are what one meant by working within shouting distance of Marxism, working on Marxism, working against Marxism, working with it, working to try to develop Marxism" (Hall, 1992: 279).

What then are the theoretical irruptions that the sociology of culture tends to forget? We can list two, and related, topics. First, the "rigorous" Marxist approach in the sociology of culture treats political economy in the fashion of system theory, or, in the Wallersteinian paradigm, as worldsystem theory. This approach defines the global operation of capitalism (and class relations, articulated in flows of capital between centres and peripheries, and within centres) as pre-structured structures of exploitation. The approach obliterates Marx's statement that history is made by people, not systems (or structures); it is thus bound to minimize the agency while overemphasizing the logic of capital. Consequently, for Wallerstein, culture (and its current globalized derivate, cultural diversity) is but an ideological tool for the prolongation of the world economy of exploitation (Wallerstein, 1990). Culture is therefore both above and beyond the people: although it is ideologically represented as a human resource, it is indeed a source of domination; and illusionism perpetuated by global capital.

For Jameson, too, postmodern cultural production is a tool of reproduction of late capitalism by means of culture. It relies on fetishization which, following the Critical Theory paradigm is prolonged from the sphere of (global) production onto the sphere of (localized) consumption. Apple iPhone

\footnotetext{
${ }^{6}$ The dialogue with Marxism was a central and formative activity not only in the case of the CCCS but mapped the theoretical and political work of cultural studies also in the US. For instance, Marxism and the Interpretation of Culture, an edited volume of contributions that were first presented at the conference at the University of Illinois in 1983, conveys a sympathetic yet critical attitude toward Marxism (Cruz, 2012: 266); this attitude remains salient also when cultural studies in the US get the more distinct visibility of an academic discipline.
} 
5 , to provide a recent example, originates in the anonymous, non-existent space of a Korean Foxconn factory in China, the epitome of the enclosed, protected and unregulated exploitation of Third World labour; 7 in the consumer hands, it is a materialization of the Western style commodification of life, predicated on branding the value, the spirit and subjectivity - freed of signs of actual labour and its human machines. Moreover, as Appadurai (1990) notes, the cultural fetishization transfers its operation onto the political - the ultimate value of choice (of consumer goods) compensates for the loss of political choice, progressive alternatives and radical change.

Interestingly enough, this hard materialist approach can be detected already in Williams. A Marxist cultural sociology, he writes, "is then recognizable, in its simplest outlines, in studies of different types of institution and formation in cultural production and distribution, and in the linking of these within whole social material processes" (Williams, 1992: 138). Although Williams puts a major emphasis on culture as a system of relations and a process, and although he, in refreshing Gramsci's hegemony, underlines the importance of "practical consciousness" and the processes of the everyday, "alternative hegemony", in conceptualizing distribution, the agency of the audiences remains limited. Thus distribution, he continues, "is not limited to its technical definition and function within a capitalist market, but connected, specifically, to modes of production and then interpreted as the active formation of readership and audiences, and of the characteristic social relations, including economic relations, within which particular forms of cultural activity are in practice carried out" (Williams, 1992: 138).

In the development of the sociology of culture, two theoretical omissions are intriguing, and, in their historical significance, resemble the above-mentioned amnesia: namely, the work of Antonio Gramsci and its upgrade theory by Laclau and Mouffe. The omission is not accidental and is, in my view, pivotal to the misunderstanding between cultural studies and the sociology of culture.

Gramsci has been an undisputed reference in Marxist theory but the fate of its key concept of hegemony is far less certain. Hegemony, as many have already pointed, is a concept developed in a sporadic manner by the imprisoned Gramsci (Williams, 1992); its elusiveness notwithstanding, it provides enough theoretical evidence to uncover the predicament that it yields. Hegemony, as discussed by Williams, goes beyond culture (Wil-

\footnotetext{
${ }^{7}$ http://www.mladina.si/115839/skrivnost-iphona/.
} 
liams, 1992: 108) and in this respect it contributes to reproduction of power in both more pervasive and less visible ways. In the process, class loses its determinist totality. For Gramsci, the organic ideology "does not represent a purely classist and closed view of the world; it is formed instead through the articulation of the elements which, considered in themselves, do not have any necessary class belonging" (Laclau and Mouffe, 1990: 68). Although as Laclau and Mouffe show, there is an inherent class naturalism even in Gramsci, an important advancement in his theory of hegemony is that it accepts social complexity as the very condition of political struggle; allows for the plurality of struggles and democratic demands that are irreducible to class belonging; and, most importantly of all, struggles in Gramsci "derive their meaning from their hegemonic articulation, and their progressive character - from a socialist point of view - is not assured in advance" (Laclau and Mouffe, 1990: 71). This last position, as I will suggest below, is indeed a major cause of the disagreement for it precludes the certainty of leadership and renders political claims to the historical role of the intellectual inherent to the hegemonic struggle itself.

The theoretical contribution of Laclau and Mouffe lies in the reconceptualization of agency. In particular, their view of history as always a contingent outcome of different struggles decomposes the unity of the class and class subject. Instead, they speak of subject positions, articulated through a web of relations, situations, locations and discourses. Although their notion of subject position is still structuralist in substance, the structure (closer to their theoretical affiliation to psychoanalysis) is open, elusive, networked along the chain of signifiers that constantly shift the alliances and loyalties. Thus the subject itself has become a hegemonic project, determined by structural nods of relations of exploitation, contributing to their reproduction by either resistance or compliance. Most importantly, either resistant or compliant, the hegemonic subject is unpredictable and, as history itself, contingent and unstable.

\section{The post-Marxist intellectual}

This complicates the Marxist paradigm in at least one important segment, namely in the realm of the political project. Hegemony means the activity of leadership that is negotiated through consensual fashion among the intellectual and civil authorities with a significant portion of public trust. As Andrew Ross (1989) brilliantly discusses the issue on the case of the 
20th century intellectual, the leadership implies - as well as produces demands for respect and faith. Players who lack either, or both, will have to invest their energies first to acquire those qualities before harvesting the role of leader; yet alone a vanguard leader. There is, however, an intrinsic historical conflict implied in this role: for Marx, the role of the revolutionary leader was clearly allocated to the class and its intellectual leadership. There was a certain "natural" affiliation that secured the Communist intellectual the hegemonic leadership in the hegemonic struggle beforehand - the revolutionary role was predetermined by the affiliation with the revolutionary class. The prestige, therefore, was secured, as was the danger of exploitation (as numerous cases in history attest) of this prestige. With Gramsci, the certainty collapses; leadership is a matter of struggle, a negotiation between and among forces of power. With the passing of time, the uncertain situation only exacerbates. The intellectual who as late as the 1960 s still could see his class mission clearly, is robbed today of the pre-located social power; he needs not only to convince the masses of his leadership, he has to struggle with others who may map the change differently.

It is not a coincidence then that the historical dispute of sociology of culture with cultural studies arises with the arrival of cultural studies in the academic field. The neuralgic point that cultural studies bring to the surface is precisely the question of class. Suddenly, class is not a homogeneous entity anymore; moreover, cultural studies research shows that it may articulate its political and historical demands in the terrains that are irreconcilable with revolutionary change to the rigorous Marxist, e.g., in the sphere of consumption. Moreover, the working class may be the ideological liaison to global exploitation of Third World labour and a contributing factor to the exploitation and, based on race, ethnicity or gender/sexuality, exclusion of groups of people at home.

To this, last but not least, cultural studies launched its own claim to (organic) intellectual leadership. "We were organic intellectuals", Hall writes, "without any organic point of reference; organic intellectuals with a nostalgia or will or hope (to use Gramsci's phrase from another context) that at some point we would be prepared in intellectual work for that kind of relationship, if such a conjucture ever appeared" (Hall, 1992: 281). This group of intellectuals, as described above, was marked by its marginality; insisted on marginality; and, when and if climbing up the hierarchical 
ladders of power, willing to, in fact, demanding always to reflect on their position of privilege.

This is a situation that can hardly be imagined, yet alone found in the context of the continental European sociology of culture academia. ${ }^{8}$ It is profoundly absent in the postsocialist universities: there are no minority intellectuals comparable to Chicana or black scholars in the US; there are no intellectual traditions of self-reflection in the system of hierarchies of power and knowledge. To the contrary, the 1968 generation of Leftist intellectuals continues to shape the postsocialist ${ }^{9}$ cultural sociology field (often in the macho version of the white male intellectual, which Ross recognizes to be a trade mark of some 1968 revolutionaries), whereas generations of cultural studies scholars limit their agenda to studying aspects of culture closest to the European culturalist tradition - with no notable consideration of the subaltern or the race issue. ${ }^{10}$

\section{Critical pedagogy: a bridge?}

"The struggle to win popular respect and consent for authority is endlessly being waged, and most of it takes place in the realm of what we recognize as popular culture" (Ross, 1989: 3). For organic intellectuals in Europe, and its postsocialist region, this "fact" is poorly acknowledged. For Marxist cultural sociology, popular culture continues to be seen within the culture industry paradigm and/or contained within the 19th century modernist view of culture as an elitist, critically enlightened practice with the potential to trickle down effects on the masses. The distance between cultural studies and the sociology of culture in understanding popular culture is somehow

\footnotetext{
${ }^{8}$ For a valubale case study discussion, see: Varsamopoulou, 2009; see also Butler, 2008.

9 The main feature of the postsocialist sociologist of culture whose intellectual formation dates back to the 1960s and 1970s is an ambigous relationship with Marxism. In the time of socialism, poststructuralism, psychoanalysis and semiotics were a major source for him/her to develop a critique of State socialism. After the collapse of socialism, a distinctive feature is his/her return to Marxist political economy. The postsocialist generation of sociologists of culture who were formed in the 1990s are closer to the tradition of cultural studies; an important theoretical source is cultural anthropology, rather than classical sociology.

${ }^{10}$ As a contrary academic and intellectual position to both, there is a new, postsocialist generation of social scientists, in particular sociologists, who practice nationalist epistemologies in both research and intellectual leadership. They are mainly involved in research and teaching in newly established regionalized private academic institutions with notable affiliation with the ruling right-wing SDS political party.
} 
explainable by different cultural histories and traditions: in the US, popular culture "has been socially and institutionally central in America for longer and in a more significant way than in Europe" (Ross, 1989: 7); in Europe, bourgeois nationalist standards of culture as art continue to prevail (Vidmar-Horvat, 2012). In a backward blow from the US to Europe, a "revolution in style, sexuality, and personal expression characterized the new grammar of dissent and the new modes of political action in ways that did not appeal to the lofty sense of cultural authority which had sustained Old Left intellectuals" (Ross, 1989: 221).

What we are witnessing, then, is a rise of new intellectuals whose social and cultural position is far less precise than it used to be: "new intellectuals are uneven participants on several fronts" (Ross, 1989: 230). Ross emphasizes that in order to be able to align with people, their attitude to everyday life and commercial culture should not have to be guilt-ridden. Furthermore, they should be able to practice "uses of history" which will depart from the usual grand narratives of modernization and will pay attention to, no matter how compromised, popular fantasies and pleasures (Ross, 1989). In a way, new intellectuals will need to take a step down from the throne of their acquired capital of authority in order to be trusted and respected and to approach the masses - not as leaders but as hegemonic mediators in joint partnership to educate the public for social change.

This also involves education in the pleasure that can be said to be a proper description of cultural pedagogy. Henry Giroux, as a leading author in the field of critical pedagogy, sees mass media texts and representations as crucially linked to "the production of mobile fields of knowledge, shifting and multiple social identities, and new cultural formations" (Giroux, 1996: 37). He warns in particular of the new conservative bloc and its attempt to seize the emerging oppositional discourses of feminism, postcolonialism and post-modernism that relies on using cultural discourse of difference, depolitization of politics and politization of culture. The task of critical pedagogy therefore is to gain skills in reading texts of popular culture as serious sites on which cultural wars and ideological struggles take place. Giroux defines the goal in concrete terms as follows: "I want to reassert the importance of critical pedagogy as a form of cultural practice which does not simply tell the student how to think or what to believe, but provides the conditions for a set of ideological and social relations which 
engender diverse possibilities for students to produce rather than simply acquire knowledge, to be self-critical about both the positions they describe and the locations from which they speak, and to make explicit the values that inform their relations with others as part of a broader attempt to produce the conditions necessary for either the existing society or a new and more democratic social order" (Giroux, 1996: 38).

This demands mastering media literacy. However, one has to be cautious: to educate the critical viewing practices demands educating pleasure without interfering with its paths of articulation, as this may be interpreted as (elite) cultural paternalism. Moreover, as Ross (1990) argues in his essay "Can cultural studies do the right thing", taking as a case study Spike Lee's film Do the Right Thing, oppositional reading is not necessary progressive. Identification with the marginalized in the text does not automatically yield the right position: the racial subaltern, for example, may become oppressive $v i s-\grave{a}$-vis the female subaltern. This means, finally, that critical pedagogy also implies a reverse process, namely that the teacher, too, is involved in the pedagogical project as its object as well as subject, cultivated in his didactic skills and theoretical platform in a way allowing for the process of teaching to become also transformative for him or her.

Stam and Shohat have applied this view to the deconstruction of Europocentrism through popular culture: "Within postmodern culture, the media not only set agendas and frame debates but also inflect desire, memory, phantasy. By controlling popular memory, they can contain or stimulate popular dynamism. The challenge, then, is to develop a media practice and pedagogy by which subjectivities may be lived and analyzed as part of a transformative, emancipatory praxis" (Stam and Shohat, 1995: 318). The authors also point out that "the question of the correctness of the texts, in this sense, is less important that the question of mobilizing desire in liberatory directions" (Stam and Shohat, 1995: 318).

In short, critical pedagogy takes popular culture, popular tastes and popular desires as vehicles of emancipation; and emancipatory practices as didactic tools towards inducing social change. How can this be acceptable for Marxist cultural sociology? Are there any historical references that can give an intellectual and theoretical support to such a position?

In the limited scope of this paper, I can only suggest a direction for further research. This is based on the argument that postsocialist culture is indeed a most appropriate cultural terrain for such a policy. It is a culture 
that continues to occupy a liminal and vaguely defined zone between Eurocentric and counter-cultural practices. In particular I think of the legacy of socialism that erected popular culture to the position of a prime site of resistance, carnivalesque and critique - while not abandoning fun, pleasure and a cosmopolitan perspective: comics culture, video, film, punk and music in general, journalism (Radio Študent and Mladina in Slovenia!), but also consumerism, Hollywood and Ponte Rosso all paved ways towards emancipation of the citizen, pluralisation of society and popular reservation for official "truths". This cultural heritage continues to exist within postsocialist culture - in the form of memory, nostalgia (Velikonja, 2008) or, as the latest case of trickster art (trio artists Janez Janša or the documentary "Houston, we have a problem" /2012/ on Tito's alleged space program) conveys, in integrating Bakhtin's carnivalesque in postsocialist capitalist society. A main difference is that, in contrast to the socialist era, when oppositional culture had to open up a space of struggle against the Communist regime, in postsocialism it has to compete against the nationalism of the State and the hegemonic public. The quest, however, remains: how to transform this oppositional culture into alternative hegemony.

Intellectuals will have a decisive say in this, but only if they learn from their historical "rights and wrongs" in relation to the popular. And this, of course, also implies a relation towards the minorities, and other subalterns within their states; and the enlarged contexts of the European Union.

\section{Conclusion: a turn in/to history}

In my analysis, I have suggested that the unfortunate relationship between cultural studies and the sociology of culture is historically generated and refers as much to the crisis of intellectual leadership as to the crisis of the critical intellectual. It is a product of the unresolved relationship with Marxism and the inability to accept new historical conditions of articulation of change in which the intellectual is but an equal player among the groups that articulate resistance and struggle. An intellectual can be a mediator, a prime agent of responsibility towards popular resistance and the history of justice; but by no means can he count on the status of the Subject who is supposed to know; with the concept of hegemony, it is clear that his struggle for social change is also simultaneously the struggle for the reproduction of his position of power. Before this relation is uncoupled 
in a reflexive manner, the authority will have to deal with low, if not "no respect" at all.

Whereas this issue, at least in structuration theory and in the postMarxist turn to Gramsci has found a partial reconciliation within Marxist sociology, it has, paradoxically remained unresolved between the sociology of culture and cultural studies. Therefore, the defence of Theory can be seen as a symptom of conflict within Marxism, whereas Cultural Studies are the ground on which the battle to restore the Marxist structuralist paradigm is taking place. In the process, both intellectual traditions are losing, and the loss is theoretical as well as political.

The antagonism engulfs an intellectual war, a war between the established discipline, which yields authority on the very basis of its anti-establishment stand and critique of the State; and the outsider whose practice from the position of a marginal discipline complicates the simple polarity between (State) power and its (academic) opposition. Therefore, the arrival of cultural studies in the academic fields is not perceived as opening up the space for hegemonic struggle, but a diversion away from the struggle. Welcoming cultural studies does not represent a process of democratization of the intellectual debate, but a distortion of radical thought. Consequently, and based on this pre-judgement, lack of dialogue, rather than a modest theoretical exchange, is employed as the hegemonic strategy itself: arguably, this has become a benchmark feature of the intellectual hegemonic practice of postsocialism.

This intellectual cultural war does not present a problem in itself. Indeed, it may not be too pretentious to argue that the resistance to cultural studies has seconded the sociology of culture to reflect on its changed historical and theoretical position. The issue becomes complicated when it is transported into the university and becomes a tool of intellectual recruitment. Then, the matter of the role of the intellectual, and the pedagogical role in particular, becomes sound and salient.

For both, cultural studies and sociology of culture intellectuals, cultural theory is a matter of conceptualizing as well as inducing social change. As can be derived from our analysis, a major dispute between the two disciplines is not in the question of the origin of domination, exploitation and subjugation of the subject; rather, the main disagreement is in the means of resolving the historical situation that subjugates the disempowered and dispossessed individual. For cultural studies, the main strategy is resistance 
through culture, which implies imaginary solutions of the real problems (Jameson, 2002) of capitalist society; for the sociology of culture, the answer is in the annihilation of the capitalist economy tout court, whereas culture is conceptualized as a vehicle for achieving the revolutionary goal. Popular fantasies therefore are by definition the obstacle on the way to change as they help reduce the tensions produced by relations of exploitation, while transcending the actual source of desubjectivation and alienation onto the substitute terrain of culture.

Any critical theory of culture would, of course, be closer to the latter than to the former position. As it follows from Marx, the intellectual worker is here not to describe and interpret but to change the world. The problem, however, is both one of a method and one of politics: in short, of hegemonic leadership. How can one educate the consciousness of people to be able to see structures underneath practices, theory below studies?

As this paper suggests, the question can be resolved via another academic paradigm. Critical pedagogy addresses the issue of public education, of cultivating the critical mind. This project relies on culture as the main field upon which education takes place; in contrast to cultural studies, it investigates popular pleasures to re-channel resistance towards a systematic pedagogical project; in contrast to the sociology of culture, it acknowledges pleasure as a site of multiple negotiations against power and control and incorporates the voices of the other into its own vocal system of pedagogy. Critical pedagogy, at its best, does not accept the position that there are only texts in the class (S. Fish); nor does it reserve for itself the ultimate position of the Subject-who-is-supposed-to-know. Truth and knowledge are social products that overlap with (come from) class (and other social) positions as well as - as we know from Bourdieu (1984) - assist class in reproducing its hierarchies in everyday life.

A joint effort of both disciplines may at first result in the undermining of the authority of the intellectual in the class; at last, it may be retroactively confirmed as the most cultivated thing to have been done in the name of social change - and the shared hegemonic participation of the educated class of people.

In postsocialist societies, where the pride of non-imperial histories in the past has obfuscated the intellectual vision of the reproduction of the imperial mind in the present, this may prove both theoretically and pedagogically, the "right thing to do". 


\section{LITERATURE}

Ang, Ien (1985). Watching Dallas: Soap Opera and the Melodramatic Imagination. London and New York: Routledge.

Appadurai, Arjun (1990). "Disjuncture and Difference in the Global Cultural Economy", in: Mike Featherstone (ed.). Global Culture: Nationalism, Globalization and Modernity. London: Sage, pp. 295-310.

Bourdieu, Pierre (1984). Distinction: A Social Critique of the Judgment of Taste. Cambridge, Mass.: Harvard University Press.

Brown, Mary Ellen (ed.) (1990). Television and Women's Culture: The Politics of the Popular. London: Sage.

Butler, Judith (2008). "Sexual Politics, Torture, and Secular Time", The British Journal of Sociology, 59 (1): 1-23. doi:10.1111/j.1468-4446.2007.00176.x

Clifford, James (1988). The Predicament of Culture: Twentieth-Century Ethnography, Literature, and Art. Cambridge, Mass.: Harvard University Press.

Cruz, Jon D. (2012). "Cultural Studies and Social Movements: A Crucial Nexus in the American Case", European Journal of Cultural Studies, 15 (3): 254-301. doi:10.1177/1367549412449724

Fiske, John (1989). Understanding Popular Culture. Boston: Unwin Hyman.

Giroux, Henry A. (1996 [1993]). Living Dangerously: Multiculturalism and the Politics of Difference. New York: Peter Lang.

Grossberg, Lawrence, Nelson, Cary and Treichler, Paula (1992). Cultural Studies. New York: Routledge.

Habjan, Jernej (2010). Dialoška struktura in družbeno učinkovanje literarnega dela. Doktorska disertacija. Ljubljana: Filozofska fakulteta.

Hall, Stuart (1992). "Cultural Studies and its Theoretical Legacies”, in: Lawrence Grossberg, Cary Nelson and Paula Treichler (eds). Cultural Studies. New York: Routledge, pp. 277-294.

Hall, Stuart (1993). “Culture, Community, Nation”, Cultural Studies, 7 (3): 349363. doi:10.1080/09502389300490251

Jameson, Fredric (1991). Postmodernism, or, The Cultural Logic of Late Capitalism. London and New York: Verso.

Jameson, Fredric (2002 [1981]). The Political Unconscious: Narrative as a Socially Symbolic Act. New York and London: Routledge.

Laclau, Ernesto and Mouffe, Chantal (1990 [1985]). Hegemony and Socialist Strategy: Towards a Radical Democratic Politics. London: Verso.

Močnik, Rastko (2009). Spisi iz humanistike. Ljubljana: *cf.

Modleski, Tania (1988 [1982]). Loving with a Vengeance: Mass-Produced Fantasies for Women. Berkeley: University of California Press.

Moores, Shaun (1993). Interpreting Audiences: The Ethnography of Media Consumption. London: Sage.

Morley, Dave (1992 [1980]). "Texts, Readers, Subjects”, in: Stuart Hall, Dorothy Hobson, Andrew Lowe and Paul Willis (eds). Culture, Media, Language: 
Working Papers in Cultural Studies, 1972-79. Birmingham: University of Birmingham, pp. 140-166.

Pribram, E. Deidre (1988). Female Spectators: Looking at Film and Television. London: Verso.

Ross, Andrew (1989). No Respect: Intellectuals and Popular Culture. New York: Routledge.

Ross, Andrew (1990). "Ballots, Bullets, or Batmen: Can Cultural Studies Do the Right Thing", Screen, 31 (1): 26-44.

Seiter, Ellen, Borchers, Hans, Kreutzner, Gabriele and Warth, Eva-Maria (1989). “'Don't Treat Us Like We're So Stupid and Naïve': Toward an Ethnography of Soap Opera Viewers", in: Ellen Seiter, Hans Borchers, Gabriele Kreutzner and Eva-Maria Warth (eds). Remote Control: Television, Audiences, and Cultural Power. London and New York: Routledge, pp. 223-247.

Spivak, Gayatri Chakravorty (1993). Outside in the Teaching Machine. New York and London: Routledge.

Stam, Robert and Shohat, Ella (1995). "Contested Histories: Eurocentrism, Multiculturalism, and the Media", in: David Theo Goldberg (ed.). Multiculturalism: A Critical Reader. Oxford: Blackwell, pp. 296-324.

Varsamopoulou, Evy (2009). "The Idea of Europe and the Ideal of Cosmopolitanism in the Work of Julia Kristeva", Theory, Culture \& Society, 26 (1): 24-44. doi:10.1177/0263276408099014

Velikonja, Mitja (2008). Titostalgia - A Study of Nostalgia for Josip Broz. Ljubljana: Peace Institute.

Vidmar Horvat, Ksenija (1995). "Raziskave sodobne kulture kot zgodovina zavesti”, Časopis za kritiko znanosti, 23 (175): 187-194.

Vidmar Horvat, Ksenija (1998). "Ameriške Cultural Studies ali Cultural Studies V Ameriki?", Časopis za kritiko znanosti, 26 (192): 267-290.

Vidmar Horvat, Ksenija (1999). "Nelagodni žanr: Soap opera in ženska publika", Delta, 5 (3-4): 109-124.

Vidmar-Horvat, Ksenija (2012). “The Predicament of Intercultural Dialogue: Reconsidering the Politics of Culture and Identity in the EU", Cultural Sociology, 6 (1): 27-44. doi:10.1177/1749975511401280

Wallerstein, Immanuel (1990). "Culture as the Ideological Battleground of the Modern World-System”, in: Mike Featherstone (ed.). Global Culture: Nationalism, Globalization and Modernity. London: Sage, pp. 31-55.

Williams, Raymond (1992 [1977]). Marxism and Literature. Oxford: Oxford University Press. 


\title{
Sociologija kulture i kulturni studiji: prema postsocijalističkoj pomirbi
}

\author{
Ksenija VIDMAR HORVAT \\ Odsjek za sociologiju Filozofskog fakulteta Sveučilišta u Ljubljani, Slovenija \\ ksenija.vidmar@ff.uni-lj.si
}

\begin{abstract}
U radu se razmatra odnos između sociologije kulture i kulturnih studija. Tvrdi se da odnos između tih dvaju pristupa kulturnoj analizi zahtijeva dublje istraživanje budući da među njima ima mnogo dodirnih točaka, ali da se, zbog uzajamnoga površnog poznavanja i nerazumijevanja istraživačkih ciljeva, njihov zajednički program često zanemaruje (ili čak opovrgava). K tomu, zajedničko naslijeđe često zamagljuje podjela na geografske i intelektualne kulture koja u grubim crtama odražava podjelu na zapadne (demokratske kapitalističke) i istočnoeuropske (postsocijalističke) epistemološke orijentacije u istraživanju društvenih promjena. Rezultat je da oba polja gube na svojoj teorijskoj i pedagoškoj moći. Rad upozorava na podrijetlo nekih međusobnih zabluda s namjerom da se ukaže na mogućnosti za uzajamno jačanje intelektualne snage pod uvjetom da sociologija kulture i kulturni studiji pomaknu svoj odnos od ignoriranja prema dijalogu.
\end{abstract}

Ključne riječi: sociologija kulture, kulturni studiji, postsocijalizam, marksizam, klasa, kritička pedagogija, intelektualci 